\title{
Tax Burden on Professional Yachting in Greece and other European Countries
}

\author{
Mihail N Diakomihalis \\ Accounting and Finance Department \\ University of Ioannina \& Hellenic Open University, Greece \\ Spyros Verginis \\ Independent Authority for Public Revenue, 31100, Lefkada, Greece
}

Received: November 29, 2019 Accepted: December 1, 2019 Published: December 4, 2019

doi:10.5296/ber.v10i1.15775 URL: https://doi.org/10.5296/ber.v10i1.15775

\begin{abstract}
This paper examines the tax approach of yachting in Greece and in other European countries such as the Netherlands and the United Kingdom, which have a long tradition in this field, as well as Croatia and Slovenia which are neighbouring and competitive countries towards Greece. According to recent surveys there have been indications that there has been a decline in yachting development in recent years, which is in sharp contrast to the comparative benefits that Greece has in this field.

With this in mind there has been a survey carried out to show whether the prevailing situation is the result not only of the financial crisis but also of the taxes imposed by the state. The results of the survey have come about by studying and comparing the tax approach of the countries mentioned above, along with an example of the main tax costs in each country as compared with the Greek taxation taking into consideration Professional yachting.

A general result is that Professional yachting has not been affected to such a degree by high taxation, but by the complexity that governs it along with the fact that the laws which have already been passed are not implemented.
\end{abstract}

Keywords: Taxation, Yachting, Greece, Europe

\section{Introduction}

Yachting is a very popular tourism activity among visitors of Greece and it is therefore a significant part of maritime tourism. This has undoubtedly contributed to the economic 
growth of coastal and insular tourist destinations and to the restraint of the local population. Yachting is regarded as a fixed asset market, with high capital investment, while it has been connected with consumers of high income choosing luxurious holidays. This last connection has influenced negatively and shaped a false image for the activity as well as an intensely erroneous view by the state which considers almost all yacht or motor-yacht owners as very wealthy citizens and charges them with high tax payments.

Taxes are contributions levied by government on income, wealth and capital gains, expenditure on goods and services, and property. In most cases, higher corporate taxes are associated with lower entrepreneurship. Although relevant empirical studies are subject to constraints and do not prove the causal link between taxation and business creation, it is reasonable to assume that taxes could reduce entrepreneurship and economic growth (Minford, 2016).

This research examines the tax approach of yachting in Greece and other European countries. The purpose of the study is to investigate whether the taxation has affected the current state of the industry and whether it is a hindrance to its development. This is achieved through the recording of the tax framework governing the sector in Greece and in the countries concerned. These countries are the United Kingdom, the Netherlands, Croatia and Slovenia. Then, looking at the results of the research, we are expected to draw useful conclusions on the way and the extent of the impact of taxation on the industry.

\section{Literature Review}

It is obvious that research on issues related to Maritime Tourism, and particularly on Yachting, is very limited, while there are almost no studies on more specific issues such as the taxation of the sector. Before referring to the tax framework governing yachting, it would be useful to refer to the findings of probably the only relevant study for Greece in 2012 by Diakomihalis, entitled "Maritime Tourism Tax Revenues in Greece: A New Framework for Collection". In this survey, it is attempted through the implementation of Touris Satellite Account (TSA) to determine whether the tax revenues of Maritime Tourism, including those of yachting, compare to budgeted tax revenues by the government, in order to determine the effectiveness of the tax system. Cruise and Coastal maritime tourism are the other two maritime activities. It emerged that yachting participates $37.55 \%$ of the total tax revenue from maritime tourism with 69.01 million euros. Nearly half of these, about 33.23 million euros, are VAT revenues, placing Yachting in the first rank among the three maritime tourism categories. Yachting ranks second in the category of net tax revenue on the production of other sectors with $39.44 \%$ (24.73 million), and due to the mooring fees and winter-shelter in the marinas and other ports, it has the highest percentage of other taxes on production with $69,72 \%$ and 11,05 million euro (Diakomihalis, 2012).

Similar surveys have been carried out by Diakomihalis and Lagos (2008), on the impact of Yachting on the Greek economy, with the implementation of the tourism satellite account. This study investigated the contribution of the sector to various sizes of the economy, including public revenues (Diakomihalis \& Lagos, 2008). Another relevant research was that aimed at exploring all activities of marine tourism in the national economy, in which the tax 
effect of Yachting (Diakomihalis, 2007) is appreciated. Other researches focus on specific topics of Yachting such as "The Role of Port and Refueling Costs in Yachting Development in Greece" (Diakomihalis, 2011) and "A Comparative study of Yachting Development in the Greek Islands and Turkish coastline" (Diakomihalis \& Atlay, 2011), as well as issues of general interest of marine tourism such as "marine tourism and its economic influences" (Diakomihalis, 2009),"Greek Maritime Tourism: Evolution, Structures and Prospects" (Diakomihalis, 2007b), "An empirical approach to coastal leisure shipping in Greece and an assessment of its economic contribution" (Diakomihalis \& Lagos, (2011) and the postgraduate thesis "Marine tourism and Greece's position-comparisons and opportunities" Hatzimanolakis, 2011). Further information on quantitative and financial data of Yachting and marine tourism in general, comes from publications in professional journals and electronic media (Kotsis, 2012; Manoglou, 2017; Mavrigiannakis, 2017; NEE, 2012; SETE, 2015; Shiahos, 2017; Fourla, 2016 and 2017).

\section{Methodology}

To answer the research question, namely how and to what extent taxation affects the operation and competitiveness of yachting in Greece, initially a legislative review has been made with the modifications that have taken place from the force of the 27/75 Law until today. Thereafter, the tax burdens on the net profits of the companies of the sector, which are either physical or legal entities of professional yachting, are recorded regarding the VAT which burdens the main costs, and any other charges or fees that are in effect. The main costs of yachting relate to the cost of purchase, the cost of chartering, mooring, supply of goods and services of the vessel and fuel costs. There is also a record of any allowances or exemptions that may be used.

In the same way, all relevant tax charges in all countries concerned have been recorded. We have attempted to record the above taxes as identical as possible for all countries in order to ensure a more reliable comparison. In the last part of the study there is a comparative example of taxation which reflects the taxcosts as a result of the way in which each country approaches taxation of the sector, along with any differences and similarities of this approach. Concluding the results of the research, apart from the useful inference and proposals, there are also included comparative tables with the results for all countries concerned.

\section{Taxation of Professional Recreation Boats in Greece}

The operation of professional recreational boats in Greece is mainly governed by the provisions of Law 4256/1914, and their tax regime is mainly governed by the provisions of Law 4256/1914, Law 277/1975 and Article 27 of Law 2859 / 2000. Specifically:

- Professional boats with Greek or foreign flags pay the annual tax on ships of Article 12 of Law 27/775 five times, and from 01-04-2018 they are obliged to pay the "Taxes of Recreational and Day Boats" (T.R.D.B.) depending on the length of the vessel. The annual objective expense does not apply to these boats and they do not pay a luxury living tax. 
- The income produced from recreation yachts is exempted from the Income Tax in accordance to the provisions of articles 1 and 2 of Law 27/75. However, individual enterprises are not exempted from the Business Tax-Fee and the Solidarity Levy.

- In respect of VAT, professional recreational craft is subject to the Special Exemptions of Article 27 of Law 2859/2000 "Valuation of Value Added Code" (Since 01/04/2018 according to Law 4514/2018, professional yachts entitled to those VAT exemptions must be more than 12 meters in length and operate on the high seas).

Private leisure crafts and professional yachts with a foreign flag do not benefit from the above exemptions

Below is the Taxation analysis of yachting by tax category.

VAT: The chartering of professional recreational craft according to article 21 of Law $2859 / 2000$ is subject to the standard VAT rate, which has been set to $24 \%$ since June01-2016.

However, because the professional recreational yachts and the tourist boats of Law 438/1976 are included in the categories of tourist ships, in accordance with the provisions of the law, the exemption of part of their gross income from VAT, has been applied according to their classification, based on the General Inspection Protocol of the Ministry of Merchant Marine or the recognized classification society.

CATEGORY I: Tourist vessels engaged in international voyages are subject to VAT deduction rate of $60 \%$.

CATEGORY II: Tourist Boats operating from Local to High Seas are subject to VAT deduction rate of $50 \%$.

CATEGORY III: Tourist Boats operating from Local to Short Seasare subject to VAT deduction rate of $40 \%$.

Essentially, the majority of professional recreational boats in Greece are classified in the second category, so their charter contracts have a VAT deduction of 50\% and the therefore rate of $12 \%$ applies.

The recreation boats have the possibility that all companies have, to join the small business regime of Article 39 and be exempted from VAT, if they also have gross revenue for the previous year of up to $€ 10,000$, which is a rare case due to the low limit of revenue.

The cost of purchasing the boat, the docking costs, the services the materials and equipment incorporated in the vessel, as well as the fuel, were exempted from the VAT according to art. 27 of Law 2859/2000, whereas from April / 01/ 2018 this only applies to boats with a length of more than $12 \mathrm{~m}$ operating in the open seas.

Besides, the professional leisure boats are exempted from custom duties for fuels they are supplied with and are granted free of charge, according to T1940 / 41 / April 14 / 2003. 
Table 1. VAT charged on the main cost categories of professional recreational boats

\begin{tabular}{|l|l|l|l|l|l|l|l|}
\hline \multicolumn{2}{|l|}{ Vat Charged On Professional Recreational Boats } \\
\hline Cost & Charter & $\begin{array}{l}\text { Aquisition } \\
\text { Of Boat }\end{array}$ & \multicolumn{2}{l|}{ Mooring } & \multicolumn{2}{l|}{$\begin{array}{l}\text { Services, Materials, Fuel, Equipment } \\
\text { Incorporated In The Vessel }\end{array}$} \\
\cline { 2 - 7 } & & & In Marinas & In Ports & $\begin{array}{l}\text { Materials And } \\
\text { Equipment. }\end{array}$ & Services & Fuel \\
\hline Vat \% & $12 \% *$ & Exemption** & Exemption** & Exemption** & $\begin{array}{l}\text { Exemp } \\
\text { Tion** }\end{array}$ & Exemption** & $\begin{array}{l}\text { Exemp } \\
\text { Tion } * *\end{array}$ \\
\hline
\end{tabular}

*It concerns vessels that, according to the General Inspection Protocol of the Ministry of Merchant Marine or the recognized classification society, have been classified in CATEGORY II

**From April/ 01 / 2018 concerns vessels with an overall length of 12 meters or more, operating on the high seas (Article 111 of Law 4514/2018 (FEK14 / 30.01.2018).) For vessels of overall length less than 12 meters, there is a charge VAT of $24 \%$.

Income tax. The net income (profit) acquired by firms, either physical or legal entities, from the operation of recreational boats is exempted from income tax in accordance to the provisions of articles 1 and 2 of Law 27/75, with the sole obligation the payment of the tax referred in Article 12 of the aforementioned Law, finishing up any tax liability.

Table 2. Scale for tax calculation of recreational boats of CATEGORY II, art.12 Law 27/75

\begin{tabular}{|l|l|l|l|l|}
\hline $\begin{array}{l}\text { Scale in G.R.T. } \\
\text { (Gross Register Tons) }\end{array}$ & $\begin{array}{l}\text { Tax rate } \\
\text { (in } \boldsymbol{€} \text { by G.R.T) }\end{array}$ & $\begin{array}{l}\text { Tax rate } \\
\text { (in } \boldsymbol{€} \text { ) }\end{array}$ & $\begin{array}{l}\text { TOTAL tonnage } \\
\text { (in G.R.T) }\end{array}$ & TOTAL Tax(in $\boldsymbol{€}$ ) \\
\hline $\mathbf{2 0}$ & 0,60 & 12 & 20 & 12 \\
\hline $\mathbf{3 0}$ & 0,70 & 21 & 50 & 33 \\
\hline $\mathbf{5 0}$ & 0,76 & 38 & 100 & 71 \\
\hline
\end{tabular}

The aforementioned tax under the provisions of Law 27/1975 (A 77), which is imposed at five times, fulfils any obligation of the ship owner as well as of the shareholder or partner of a domestic or foreign company of any type of income tax, with respect to the profits that arise from the operation of ships.

However, within the framework of the memorandum agreement, a special solidarity levy was imposed with Article 43A of the Income Tax Code (Law 4172/2014, A '167), which was added by article 112 clause 9 of Law 4387/2016 (A' 85). The solidarity levy is imposed only on the profits of Physical Entities, in opposition to Legal Entities and Maritime Companies of Recreational Boats (M.C.R.B.) which are exempted.

Table 3. Scale for Solidarity Levy

\begin{tabular}{|l|l|l|l|l|l|}
\hline Income & Rate & Income & Rate & Income & Rate \\
\hline $0-12.000 €$ & $0 \%$ & $20.001-30.000$ & $5 \%$ & $40,001-65.000$ & $7,5 \%$ \\
\hline $12.001-20.000$ & $2,20 \%$ & $30.001-40.000$ & $6,5 \%$ & $65.001-220.000$ & $9 \%$ \\
\hline$>220.000$ & $10 \%$ & & & & \\
\hline
\end{tabular}

Another fee charged upon all companies, with no exemption for recreational boat companies, is the business tax introduced by Article 31 of Law 3986/2011 and which, after the various codifications, is calculated as shown below in the Table 4: 
Table 4. Business Tax

\begin{tabular}{|l|l|l|l|}
\hline Business Tax & City of Head Office (population) & Head Office & Branch Office \\
\hline \multirow{2}{*}{ Legal Entities } & $>200.000$ & $1000 €$ & $600 €$ \\
\cline { 2 - 4 } & $<200.000$ & $800 €$ & $600 €$ \\
\hline Physical Entities & Regardless & $650 €$ & $650 €$ \\
\hline
\end{tabular}

Finally, according to the provisions of article 13 of Law 4211/2013 (A'256) as it has been superseded and has been in force since April / 01/ 2019, a special fee for the State, entitled "Tax of Recreational and Day Boats", which shall be borne by: (a) private and professional recreational crafts.

The TRDB is imposed on all recreational crafts operating in all Greek territorial waters, irrespective of their flag.

Table 5. Tax of Recreational and Day Boats (TRDB)

\begin{tabular}{|l|l|l|l|}
\hline Overall Boat Length & TRDB / month & TRDB /year & Penalty fee \\
\hline Between 7 to 8 meters & $16 €$ & $192 €$ & $382 €$ \\
\hline Between8to 10meters & $25 €$ & $300 €$ & $600 €$ \\
\hline Between10to 12meters & $33 €$ & $396 €$ & $796 €$ \\
\hline Between12to 13meters. & $96 €$ & $1152 €$ & $2.252 €$ \\
\hline Between13to 14meters & $104 €$ & $1248 €$ & $2.348 €$ \\
\hline Between14to 15meters & $112 €$ & $1344 €$ & $2.444 €$ \\
\hline Between15to 16meters & $120 €$ & $1440, €$ & $2.540 €$ \\
\hline
\end{tabular}

Consequently, summarizing the above with respect to the Income Taxation and the burden of taxes, levies, fees, etc. on the enterprises operating recreational crafts, the tax treatment of professional recreational crafts depending on the form of the business, can be shown in the table below:

Table 6. Taxes and Fees (except V.A.T.) imposed on the enterprises operating recreational crafts in Greece

\begin{tabular}{|l|l|l|l|l|l|}
\hline & Income Tax & Boat Tax & Trdb & Solidarity Levy & $\begin{array}{l}\text { Business } \\
\text { Tax-Fee * }\end{array}$ \\
\hline Physical Entities & $\begin{array}{l}\text { NO } \\
\text { (Art.2 Law.27/75) }\end{array}$ & $\begin{array}{l}\text { YES } \\
\text { (Art.12 Law.27/75) }\end{array}$ & $\begin{array}{l}\text { YES } \\
\text { (Law 4504/17) }\end{array}$ & $\begin{array}{l}\text { YES } \\
\text { (Law 4172/14) }\end{array}$ & $\begin{array}{l}\text { YES } \\
\text { (Law3986/2011) }\end{array}$ \\
\hline $\begin{array}{l}\text { Legal Entities } \\
\text { - M.C.R.B }\end{array}$ & $\begin{array}{l}\text { NO } \\
\text { (Art.2 Law.27/75) }\end{array}$ & $\begin{array}{l}\text { YES } \\
\text { (Art.12 Law.27/75) }\end{array}$ & $\begin{array}{l}\text { YES } \\
\text { (Law 4504/17) }\end{array}$ & $\begin{array}{l}\text { NO } \\
\text { (Law 4172/14) }\end{array}$ & $\begin{array}{l}\text { YES } \\
\text { (Law3986/2011) }\end{array}$ \\
\hline
\end{tabular}

* Under certain conditions

\section{Taxation of Professional Recreation Boats in other European Countries}

\subsection{United Kingdom}

Income Tax. The net income (profit) resulting from the operation of recreational boats in the United Kingdom is taxed on the basis of the income tax rate of physical or legal entities. This taxation does not differ from the tax of other businesses of the British economy and ranges from $20 \%$ to $45 \%$ for the income of individuals and for legal entities $19 \%$ for all income levels. 
VAT. Chartering leisure boats in the United Kingdom is subject to the normal VAT rate, which amounts to $20 \%$ since January 4, 2011 (from 17.5\% previously). The major costs incurred by the industry, such as the acquisition of a boat, berthing, maintenance and repairs, the purchase of materials and equipment incorporated therein, and the purchase of fuel, are also subject to $20 \%$ rate without any exemption or reduced rate.

The only option an enterprise has to be exempted from the above costs is its option not to register in the VAT registration if its gross income from sales of goods and services that are not VAT exempted, does not exceed $£ 85,000$ (VAT excluded) or its purchases from businesses exempted from VAT do not exceed $£ 85,000$ over a 12 -month period, which might not necessarily be a calendar year.

No VAT exemption is provided for the acquisition of a leisure boat, but the enterprise is allowed to claim tax refunds if they are included in the Capital Goods Program and the purchase cost of the asset is equal to or more than $£ 50,000$ excluding VAT. The above settings can be used by all businesses and not just those engaged in yachting. Finally, in the United Kingdom, professional recreational craft is not burdened with other special taxes or fees.

Table 7. United Kingdom-Major Taxation burdens on professional recreation boats

\begin{tabular}{|c|c|c|c|c|c|c|c|}
\hline \multicolumn{5}{|c|}{ Income Tax Scale } & \multicolumn{3}{|l|}{ V.A.T. } \\
\hline \multicolumn{4}{|c|}{ Physical Entities } & \multirow[t]{2}{*}{ Legal Entities } & \multirow[t]{2}{*}{ Charter } & \multirow[t]{2}{*}{ Mooring } & \multirow[t]{2}{*}{ Maintenance \& Repairs } \\
\hline In $0,000 €$ & 38.400 & 172.000 & $>172.000$ & & & & \\
\hline Rate (\%) & 20 & 40 & 45 & 19 & 20 & 20 & 20 \\
\hline
\end{tabular}

\subsection{Croatia}

Income Tax. The tax treatment of recreational craft is almost unchanged from other sectors in Croatia. Income Tax rate of physical entities is $24 \%$ for income up to $€ 28,188$ and $36 \%$ for excess, while for legal entities is $12 \%$ for income up to $€ 400,000$ and $36 \%$ for excess.

For small enterprises, with gross income $<300,000 \mathrm{HRK} \neq € 40,000)$ and only for physical entities there is the possibility of joining the special Status of Small Enterprises and be taxed at a flat rate of $12 \%$ for $15 \%$ of their gross income which is considered as taxable profit. (Republic of Croatia, 2018a and 2018b).

V.A.T. In Croatia the amount of VAT charged on leisure boat hiring depends on whether or not overnight accommodation is also provided. Specifically:

Daily rent of a leisure boat is charged at the standard rate of $25 \%$, but renting of a leisure boat including overnight accommodation is charged at the reduced rate of $13 \%$ because it is considered as a residence service (Republic of Croatia, 2018c).Consequently, rental of recreational boats in Croatia is subject to a reduced VAT rate of $13 \%$ in most cases, as statistically, almost all rentals of recreational boats include an overnight stay. There is a possibility of VAT exemption in the case of joining the Special Status of Small Enterprises if the gross income of a business is less than $€ 300,000$, the same condition as for Income Tax. 


\section{MInstitute Macrothink $_{\text {Int }}$}

The main costs borne by the industry, such as the purchase of a boat, docking, maintenance and repairs, the purchase of materials and equipment incorporated therein and the purchase of fuel, are also subject to the standard rate of $25 \%$ without any exemption or use of a reduced rate.

VAT Fee on a proportionate basis of chartering, part of which is carried out in Croatian territorial waters (Directive 410-01 / 17-01 / 1060 / 22-05-2017)

From May 1 2017, all recreational boats commencing a charter from a third country with a part of the charter time taking place in Croatian territorial waters, will have to pay VAT to the Croatian state proportionally, which corresponds to that time of traveling in Croatian national seas. The tax base for chartering a boat (with or without accommodation) is the proportionate part of the value of the contractual boat charter actually used in the Republic of Croatia (days of cruise in the Republic of Croatia, including the day of departure from Croatia, as part of the total chartering period).

\section{Other Taxes - Tourist Tax - Sojourn Tax Fee}

In Croatia, owners of recreational craft (irrespective of their flag) are required to pay a Tourist Sojourn Tax.

This tax is calculated:

- For professional leisure boats with Croatian flag which begin their tour from Croatian ports, depending on the overnight stays and the number of passengers staying overnight, the Sojourn Tax is estimated to be $€ 1.08$ ( 8 HRK) per passenger, per night (Croatian Parliament, 2008) ).

- For foreign-registered recreational craft entering Croatian waters (treated as private leisure crafts), if it exceeds 5 meters, a flat-rate tax is applied, depending on the length of the vessel and the time the vessel remains in the Croatian territorial sea and its passengers are staying overnight, ranging from 8 days to 1 year (Republic of Croatia - Ministry of Tourism, 2009).

Table 8. Major Taxation burdens on professional recreation boats with Croatian flag

\begin{tabular}{|l|l|l|l|l|l|l|l|l|}
\hline \multicolumn{2}{|l|}{ Income Tax Scale } & \multicolumn{2}{l|}{ V.A.T. } & \multicolumn{2}{l|}{ Tourist Tax } \\
\hline \multicolumn{2}{|l|}{ Physical Entities } & \multicolumn{2}{|l|}{ Legal Entities } & Charter & Mooring & $\begin{array}{l}\text { Maintenance } \\
\text { \& Repairs }\end{array}$ & \\
\hline In 0,000 € & 28.188 & $>28.188$ & $<400.000$ & $>400.000$ & & & & 1,08 \\
\hline Rate (\%) & 24 & 36 & 12 & 18 & 13 & 25 & 25 & $\begin{array}{r}\text { passenger } \\
\text { overnight }\end{array}$ \\
\hline
\end{tabular}

\subsection{Slovenia}

\section{Income tax:}

Net Income (profit) arising from the exploitation of recreational craft in Slovenia is taxed on the basis of the Income Tax Scale of the Physical or Legal Entities. 


\section{$\triangle 1$ Macrothink}

Business and Economic Research ISSN 2162-4860 2020, Vol. 10, No. 1

Tax rates for Physical Entities range from 16\% to 50\%, and 19\% for Legal Entities (Republic of Slovenia - Ministry of Finance, 2018).

As in the case of Croatia, under certain conditions, income of personal enterprises and companies having gross income of less than $€ 50,000$ in the current year or less than $€ 100,000$ in the previous year, may be optionally taxed at a rate of $20 \%$ by setting their taxable net income at $20 \%$ of their gross income, after deducting $80 \%$ as a flat-rate expenses without an invoice or a voucher.

\section{V.A.T.}

In Slovenia, income from recreational craft operation is subject to the normal VAT rate of $22 \%$. Also, the main costs incurred by the industry, such as the purchase of boats, docking, maintenance and repairs, the purchase of materials and equipment incorporated in them and the purchase of fuel, are subject to the standard rate of $25 \%$. The only possibility to exempt VAT is applied to the Small Enterprises Status where VAT is exempted if the taxable income does not exceed $€ 50,000$ over the previous 12 months (Republic of Slovenia - Ministry of Finance, 2016).

\section{Other Taxes - Tourist Tax}

The Tourist Tax is paid by the owners of boats who may be public and private legal entities, sole proprietorships and independent private entrepreneurs (individual enterprises), whose vessel has a permanent berth in a tourist port (marina), and it is charged for the overnight staying of the owners or other persons (tourists) on the boat.

The lump sum of the Tourist Tax may not exceed:

- For vessels up to 10 meters in length - 800 points $\mathrm{x} 0,115 €$ per point.

- For vessels over 10 meters in length - 1200 points $\mathrm{x} 0,115 €$ per point.

The amount of Tourist Tax is determined by the municipality on a scale of 3 to 11 points depending on the facilities and services provided (Republika Slovenija - Ministrstvoza Finance, 2017).

Table 9. Major Taxation burdens on professional recreation boats in Slovenia

\begin{tabular}{|c|c|c|c|c|c|}
\hline \multirow{8}{*}{$\begin{array}{l}\text { INCOME } \\
\text { TAX SCALE }\end{array}$} & \multicolumn{4}{|c|}{ PHYSICAL ENTITIES } & \multirow{3}{*}{$\begin{array}{l}\text { LEGAL } \\
\text { ENTITIES } \\
\text { Tax Rate } \\
\%\end{array}$} \\
\hline & \multicolumn{2}{|c|}{ Taxable Income } & Income Tax & Tax Rate & \\
\hline & From EUR & Upto EUR & & $\%$ & \\
\hline & 0.00 & $8.021,34$ & 0.00 & 16 & 19 \\
\hline & $8.021,34$ & $20.400,00$ & $1.283,41$ & 27 & 19 \\
\hline & $20.400,00$ & $48.000,00$ & $4.625,65$ & 34 & 19 \\
\hline & $48.000,00$ & $70.907,20$ & $14.009,65$ & 39 & 19 \\
\hline & Exceeding & - & $22.943,46$ & 50 & 19 \\
\hline \multirow[t]{2}{*}{ V.A.T. } & Charter & Mooring & Maintenance \& Repairs & Boat Acquisition & \\
\hline & 22 & 22 & 22 & 22 & \\
\hline \multirow[t]{2}{*}{ Tourist Tax } & \multicolumn{5}{|c|}{ For boats with a length up to $10 \mathrm{~m}-\max 800$ pointsX $0,115 € /$ point } \\
\hline & \multicolumn{5}{|c|}{ For boats with a length over $10 \mathrm{~m}-\max 1200$ pointsX $0,115 € /$ point } \\
\hline
\end{tabular}




\subsection{Netherlands}

\section{Income tax}

There is no differentiation in how to tax net income (profit) from the operation of recreational crafts in the Netherlands in relation to the net income resulting from other activities. Thus the net income (profit) of Physical Entities is taxed at a rate of $36.55 \%$ to $51.95 \%$ for income above $€ 68,507$, while the income of Legal Entities is taxed at a rate of $20 \%$ for income up to $€ 200,000$ and $25 \%$ for the excess.

Table 10. Income Tax Scale

\begin{tabular}{|l|l|l|l|l|l|l|l|}
\hline & \multicolumn{4}{|l|}{ PHYSICAL ENTITIES } & \multicolumn{2}{l|}{ LEGAL ENTITIES } \\
\hline In 0,000 € & $<20.142$ & $>20.142$ & $>33.994$ & $<68.507$ & $>68.507$ & $<200.000$ & $>200.000$ \\
\hline Rate (\%) & 36,55 & 40,85 & 40,85 & 40,85 & 51,95 & 20 & 25 \\
\hline
\end{tabular}

\section{V.A.T.}

The VAT treatment of recreational craft in the Netherlands is different regarding boats up to 24 meters of length and super yachts with a length of more than 24 meters which have been designated by the tax administration as commercial cruising vessels (CCV) and will be examined separately.

The chartering of professional recreational boats in the Netherlands is subject to the normal VAT rate which amounts to $21 \%$. The s-Hertogenbosch Court of Appeal has recently decided, following HISWA's appeal, that the hiring of closed-type recreational craft (sailboats) must be, according to the European Directive, subject to the low VAT rate of $6 \%$. This is so because it should be considered as a sporting activity and the $6 \%$ rate is also applied to open-ended boats since 2016. The above court decision is not final though.

The main costs incurred by the industry are ship purchase, docking, maintenance and repair services, the purchase of materials and equipment incorporated in them and the fuel purchase, which are subject to a standard rate of $21 \%$. The possibility of VAT exemption exists only for the Special Status of Small Enterprises with a limit of $€ 10,000$ gross income which practically makes this possibility of VAT exemption virtually inapplicable.

\section{CCV (Commercial Cruising Vessels)}

In the Netherlands there is a different tax treatment for the purchase, operation and sale of recreational boats of more than 24 meters in length which are also referred to as "small cruise ships" and are equated with ships used in open seas navigation and perform passenger transportation or commercial activity. Similarly, it is now also applied in Greece for boats over $12 \mathrm{~m}$ in length, based on the L.4144 / 2018 (FEK14 / 30.01.2018). The result of this distinction is that recreational boats belonging to the CCV category have the benefits deriving from Article 148 of the European Directive 2006/112 / 28-11-2006 on the common system of value added tax, namely the exemption from VAT of the following acts: 
- The acquisition and import of ships used in open seas navigation, except for recreational crafts.

- Goods destined for ships used for open seas navigation which are necessary for the conduct of commercial activities.

- Services related to the above goods.

- The transfer of persons from ships used in open seas navigation if the place of destination or the place of embarkation is outside the Netherlands.

\section{Criteria for $\mathrm{CCV}$ tax regime}

- The vessel must comply with the technical conditions laid down in the Code of Larger Commercial Boats.

- The boat can operate unlimited trips.

- The vessel has a total length of more than 24 meters.

- The vessel has commercial use, operates at standard market prices and is used for the carriage of passengers.

- The vessel is operated by an independent charter company established in the Netherlands where at least two people are employed as crew of the vessel, one of which is the master of the vessel.

- The vessel is registered under the Dutch flag.

Establishing this special tax regime combined with a high level of know-how, skilled shipbuilders and staff, marketing, etc. the Netherlands has, definitely played a major role for achieving the second place on the basis of the total length of vessels on the international super yachts construction market with $15.35 \%$ in 2012. According to the HISWA Water Sports Association this figure in 2015 amounts to 19, 1\% with 22 yacht deliveries.

Table 11. V.A.T. burden on the main costs of professional recreation boats in the Netherlands

\begin{tabular}{|c|c|c|c|c|c|c|c|}
\hline \multirow{4}{*}{$\begin{array}{l}\text { Recreation } \\
\text { al Boats } \leq \\
24 \mathrm{M} .\end{array}$} & \multicolumn{7}{|c|}{ V.A.T. Burden On The On The Main Costs Of Professional Recreation Boats } \\
\hline & \multirow{2}{*}{ COST } & \multirow[t]{2}{*}{ Charter } & \multirow[t]{2}{*}{$\begin{array}{l}\text { Boat } \\
\text { Acquisition }\end{array}$} & \multirow[t]{2}{*}{ Mooring } & \multicolumn{3}{|c|}{$\begin{array}{l}\text { Materials, Equipment And Services } \\
\text { Incorporated In The Boat Acquisition }\end{array}$} \\
\hline & & & & & $\begin{array}{l}\text { Materials And } \\
\text { Equipment }\end{array}$ & Services & Fuel \\
\hline & VAT Rate & $21 \%$ & $21 \%$ & $21 \%$ & $21 \%$ & $21 \%$ & $21 \%$ \\
\hline \multirow{3}{*}{$\begin{array}{l}\text { Vessels } \\
\text { CCV > } 24 \\
\text { M. }\end{array}$} & \multirow{2}{*}{ Cost } & Charter & $\begin{array}{l}\text { Boat } \\
\text { Acquisition }\end{array}$ & Mooring & \multicolumn{3}{|c|}{$\begin{array}{l}\text { Materials, Equipment And Services } \\
\text { Incorporated In The Boat Acquisition }\end{array}$} \\
\hline & & & & & $\begin{array}{l}\text { Materials And } \\
\text { Equipment }\end{array}$ & Services & Fuel \\
\hline & Vat Rate & Exemption* & Exemption & $21 \%$ & Exemption & Exemption & Exemption \\
\hline
\end{tabular}

* If the place of destination or the place of embarkation is outside the Netherlands.

There are no other taxes burdenon professional Yachting in Netherlands.

\section{Empirical Investigation of Comparative Taxation}

In order to fulfill the purpose of the study and make clear all the tax differences that have been cited in the survey, making it therefore possible to reveal the different tax approaches to yachting in the countries concerned, we will present an intimate example of tax treatment of a 


\section{Macrothink}

leisure boat and the total annual tax burden charged by each of the mentioned countries.

\section{Example Data}

After empirical research on the Yacht market in Greece and in the other four European countries, we proceeded with a brain storming among the industry's experts and finally came up with the time, cost, charter conditions and all other characteristics of the vessel that will be the subject of the comparative study, as outlined in Tables 12 and 13, which is considered the most representative case in the field of professional yachting.

Table 12. Yacht characteristics

\begin{tabular}{|l|l|}
\hline Type & Sailing Yacht \\
\hline Total length (LOA) & 12 meters \\
\hline Capacity & Sleeping Cabins 3, for 6 persons \\
\hline Gross Registered Tonnage, (G.R.T.) & 19,05 \\
\hline Net Registered Tonnage(N.R.T.) & 17,80 \\
\hline Engine Power inhp & 29 \\
\hline Engine Power inKw & $21,63(1 \mathrm{hp}=\mathbf{0 . 7 4 5 6 9 9 8 7 2} \mathrm{kW})$ \\
\hline Age & $5-10$ years \\
\hline
\end{tabular}

Table 13. Type, Time and Charter cost

\begin{tabular}{|l|l|}
\hline Annual mean Charter Time & 17 weeks \\
\hline Weekly mean Charter Cost & $\begin{array}{l}1150 € \text {, after Agents' Commission, plus V.A.T. } \\
\text { (low season } 850 €+\text { high season } 1450 € \text { ) }\end{array}$ \\
\hline Charter Type & bareboat \\
\hline
\end{tabular}

Taking into account the above characteristics and economic data, we will determine the amount of the annual tax burden of the particular vessel on a country-by-country basis, for the professional yacht which is available to be chartered with the characteristics of the charter referred to above.

\section{ie. Professional recreational craft - Operated by a Physical Entity}

In this case, we will first determine the annual net profits arising from the operation of the vessel in Greece (Table 14), with an average charter time of 17 weeks X $1.450 €$ per week (Table 13), after deducting fixed costs out of gross income.

Subsequently, the Income Tax (Physical Entity) which is attributable to the specific net profits based on the tax rates applicable per country is calculated, as well as the VAT charged to the main inelastic costs (Table 14) with any other taxes and fees, so that the total annual tax burden (Income Tax, + VAT + Other Taxes) that will be charged to the particular vessel by country, on behalf of the Yacht owner and the charterer, will ultimately be calculated. (Tables $15,16,17,18,19)$. 
Accordingly, the same total annual tax expense will then be calculated, for the operation of the Yacht by a Legal Entity, differentiated only by the cost of the Income Tax, which will be calculated by the applicable tax rates of the Legal Entities per country (Table 20). By this assessment it will be possible to compare the annual tax costs borne by the recreational boat by country and in each case, which concerns the total Tax Cost, Income Tax, VAT of the main expenses, and the amount of other taxes and fees.

In the case of a professional craft, the following data will apply for the empirical example:

- we will assume that the level of profits and expenses is the same in all the countries under consideration, with the rest of the data stable.

- Income tax as shown in Tables 15, 16, 17, 18 and 19 has been calculated based on the Income Tax Scale of Physical Entities per country. For Legal Entities, it was calculated as shown in Table 20.

- Fuel costs were calculated at a total annual consumption of 600 liters to $1.4 €$ per liter, of which 200 are for the operating company (sailing of vacant boats, maintenance) and the remaining 400 liters for charterers.

- In the case of Greece, no business tax was calculated (subjective exemption criteria apply).

Table 14. Annual Net Profit of Professional yacht Operation

\begin{tabular}{|l|l|l|}
\hline Annual Chartering Revenue 17 weeksX 1150 $€$ & & $\underline{\mathbf{1 9 . 5 5 0} €}$ \\
\hline Minus Annual fixed inelastic cost* & $€$ & \\
\hline Fuel (sailing of vacant boats, maintenance) 200 lt X 1,40 & 280 & \\
\hline Summer shelter in Marina & 2.400 & \\
\hline Winter shelter, lift, launch, and lying ashore & 1.500 & \\
\hline Maintenance (Moravia copper paint, rubbing, painting, polishing) & 250 & \\
\hline Maintenance spare parts 750€ + service 150€ & 900 & \\
\hline Certifications (Fire extinguishers, Liferafts,V.H.F.,Epirbs) & 1.000 & \\
\hline Insurance & 850 & \\
\hline TOTAL & $\underline{\mathbf{7 . 1 8 0}}$ & \\
\hline Annual Net Profit of Professional yacht Operation, of 12 meters LOA $* *$ & $\underline{\mathbf{1 2 . 3 7 0 €}}$ \\
\hline
\end{tabular}

Source: Authors' empirical research.

* The data listed in the example are approximated, drawn from empirical research by industry professionals in Greece, and costs were taken into account as reflected in the survey of the importance of recreational boats to marine tourism and the national economy of the Hellenic Chamber of Shipping (H.C.S.) in 2012.

** The resulting net profits are indicative and configured for comparison and for the purpose of the research, since no Financial Expenses, Management Expenses, Depreciation, etc. have been calculated.

Table 15. UNITED KINGDOM, Annual Total Tax Burden of Professional Yacht (of the comparative case study)

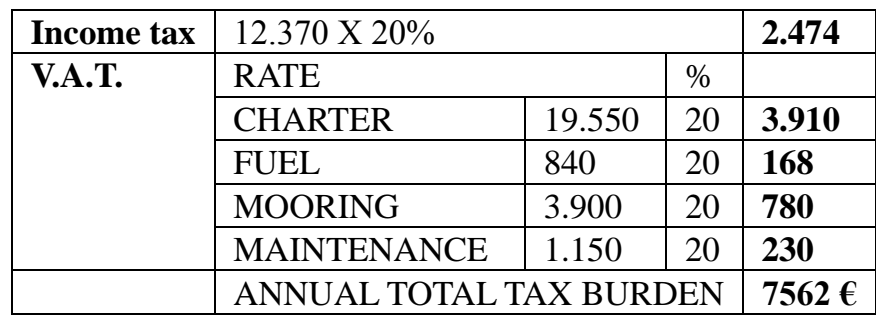




\section{Ml Macrothink}

Business and Economic Research ISSN 2162-4860 2020, Vol. 10, No. 1

Table 16. CROATIA Annual Total Tax Burden of Professional Yacht (of the comparative case study)

\begin{tabular}{|l|l|l|l|l|}
\hline Income tax & \multicolumn{2}{|l|}{12.370 X 24\% } & $\mathbf{2 . 9 6 9}$ \\
\hline \multirow{4}{*}{ V.A.T. } & RATE & 19.550 & $\%$ & \\
\cline { 2 - 5 } & CHARTER & 840 & 13 & $\mathbf{2 . 5 4 2}$ \\
\cline { 2 - 5 } & FUEL & 3.900 & 25 & $\mathbf{2 1 0}$ \\
\cline { 2 - 5 } & MOORING & 1.150 & 25 & $\mathbf{9 7 5}$ \\
\cline { 2 - 5 } & MAINTENANCE & 25 & $\mathbf{2 8 8}$ \\
\hline \multirow{2}{*}{ TOURIST TAX } & \multicolumn{2}{|l|}{17 weeksX 7 days =119 overnight stayX 6 persons $=714$ X $1,08 € /$ person } & $\mathbf{7 7 1}$ \\
\hline & ANNUAL TOTAL TAX BURDEN & $\mathbf{7 . 7 5 5} €$ \\
\hline
\end{tabular}

Table 17. SLOVENIA Annual Total Tax Burden of Professional Yacht (of the comparative case study)

\begin{tabular}{|c|c|c|c|c|}
\hline \multirow{2}{*}{$\begin{array}{l}\text { Income tax } \\
\text { V.A.T. }\end{array}$} & \multicolumn{3}{|c|}{$(8021,34 \times 16 \%)+(4348,66$ X 27\%) } & 2.458 \\
\hline & \multicolumn{2}{|l|}{ RATE } & \multicolumn{2}{|l|}{$\%$} \\
\hline & CHARTER & 19.550 & 22 & 4.301 \\
\hline & FUEL & 840 & 22 & 185 \\
\hline & MOORING & 3.900 & 22 & 858 \\
\hline & MAINTENANCE & 1.150 & 22 & 253 \\
\hline TOURIST TAX & \multicolumn{3}{|l|}{$1200 \times 0,115$} & 138 \\
\hline & \multicolumn{3}{|c|}{ ANNUAL TOTAL TAX BURDEN } & $8.193 €$ \\
\hline
\end{tabular}

Table 18. NETHERLANDS* Annual Total Tax Burden of Professional Yacht (of the comparative case study)

\begin{tabular}{|c|c|c|c|c|}
\hline \multirow{2}{*}{$\begin{array}{l}\text { Income tax } \\
\text { V.A.T. }\end{array}$} & \multicolumn{3}{|l|}{$12.370 \times 36,55 \%$} & 4.521 \\
\hline & \multicolumn{2}{|l|}{ RATE } & \multicolumn{2}{|l|}{$\%$} \\
\hline & CHARTER & 19.550 & 21 & 4.106 \\
\hline & FUEL & 840 & 21 & 176 \\
\hline & MOORING & 3.900 & 21 & 819 \\
\hline & MAINTENANCE & 1.150 & 21 & 242 \\
\hline & \multicolumn{3}{|c|}{ ANNUAL TOTAL TAX BURDEN } & $9.864 €$ \\
\hline
\end{tabular}

*Does not apply to CCV yachts

Table 19. GREECE, Annual Total Tax Burden of Professional Yacht (of the comparative study)

\begin{tabular}{|c|c|c|c|c|}
\hline \multirow{2}{*}{\begin{tabular}{|l|} 
Income tax \\
V.A.T.
\end{tabular}} & \multicolumn{3}{|l|}{$12.370 \times 2,20 \%$} & \multirow{3}{*}{$\begin{array}{l}272 * \\
2.346 \\
\end{array}$} \\
\hline & \multicolumn{2}{|l|}{ RATE } & \multirow{2}{*}{$\begin{array}{l}\% \\
12\end{array}$} & \\
\hline & CHARTER & 19.550 & & \\
\hline & FUEL & 840 & EXEMPTION & - \\
\hline & MOORING & 3.900 & EXEMPTION & - \\
\hline & MAINTENANCE & 1.150 & EXEMPTION & - \\
\hline Yacht Tax rate by G.R.T & \multicolumn{3}{|c|}{ g.r.t. $19,05 \times 0,60=11,43 \times 12$} & 137 \\
\hline TRDB & \multicolumn{3}{|l|}{$12 \times 33$} & 396 \\
\hline & \multicolumn{3}{|c|}{ ANNUAL TOTAL TAX BURDEN } & $3,151 €$ \\
\hline
\end{tabular}

* It is a Solidarity Levy and not an Income tax 


\section{Professional Recreational Yacht operatedby a Legal Entity}

In the case where the yacht belonged to a Legal Entity the only difference in the annual total tax burden is the replacement in the above tables of the Income Tax of Physical Entities with the Income Tax of Legal Entity per country, which will be formed as follows:

Table 20. Annual Total Tax Burden of Professional Yacht operated by a Legal Entity

UNITED KINGDOM: $12.370 \times 19 \%=2.350 €+$ other Tax Burdens $=\mathbf{7 4 3 8 €}$

CROATIA: $12.370 \times 12 \%=1.484 €+$ other Tax Burdens $=\mathbf{6 . 2 7 0} €$

SLOVENIA: $12.370 \times 19 \%=2.350 €+$ other Tax Burdens $=\mathbf{8 . 0 8 5} €$

NETHERLANDS: $12.370 \times 20 \%=2.474 €+$ other Tax Burdens $=\mathbf{7 . 8 1 7} €$

GREECE: Legal Entities in Greece are not entitled to Solidarity Levy, and the Net Profit from the Recreational yacht operation are Tax exempted $805-272=533 €+$ other Tax Burdens $=\mathbf{2 8 7 9 €}$

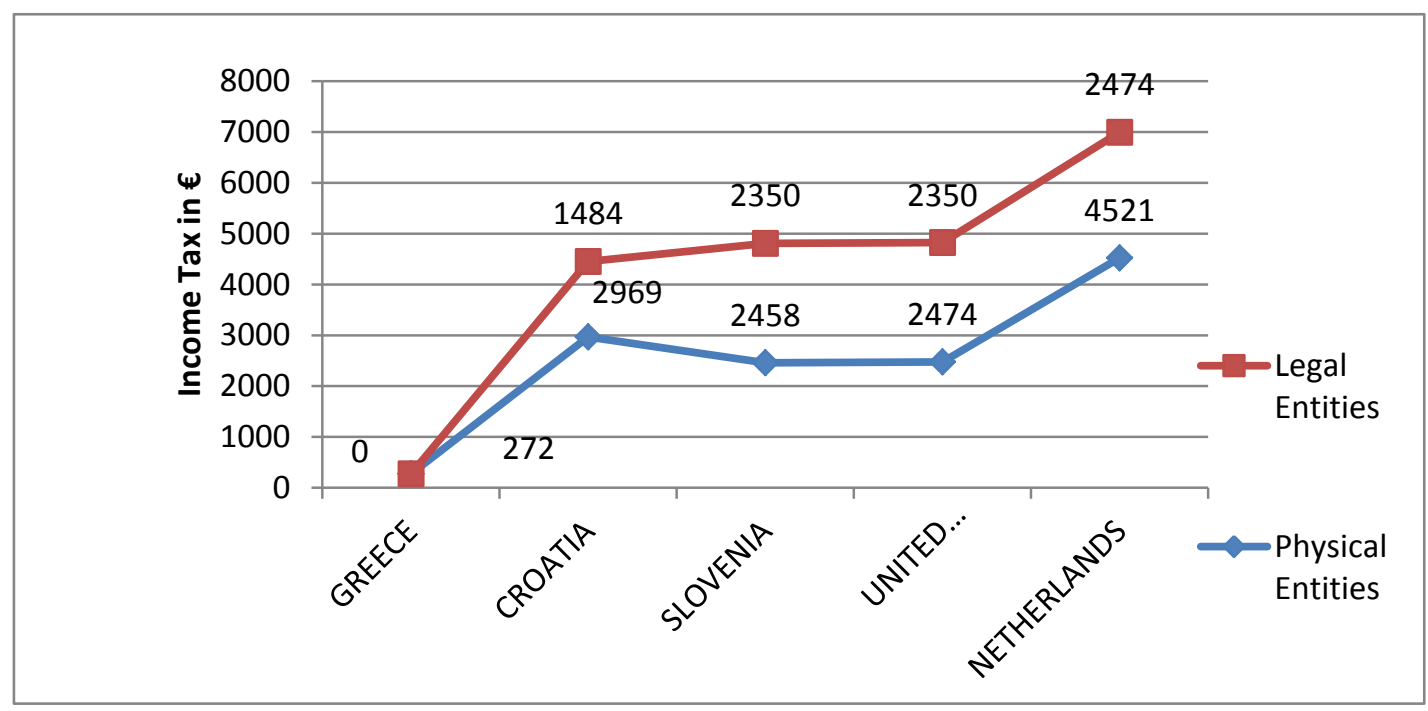

Fegure 1. Income Tax burden on the professional yacht by country

Considering the structure of the total tax burden on the professional boats in these countries, we revealed that the main tax burdens on the recreational boats are the Income Tax and VAT on chartering, followed by VAT on docking, maintenance and other taxes. Accordingly, it does not appear that the Income Tax cumulatively with the VAT of the Charter varies in all countries by more than $70 \%$ of total tax costs. This practically means that countries wishing to become more competitive in the yachting market have focused their interest on shaping the appropriate tax policy on these two costs. Thus in Greece, the net profits from the exploitation of a leisure boat are tax exempted (L.27 / 75) and the VAT of chartering is reduced by $50 \%$ in most chartering, and is configured to $12 \%$. Croatia also applies a reduced VAT rate of $13 \%$ to most charters, while the corporate income tax applies a $12 \%$ tax rate, well below the other countries, but this is not only applied on yachting.

The remaining costs charged with VAT, such as docking and maintenance costs, with the exception of Greece where an exemption is applied (Law 8271 / 87), do not have any significant difference in the other countries under comparison. These rates are $25 \%$ in Croatia, 


\section{Macrothink}

Business and Economic Research ISSN 2162-4860 2020, Vol. 10, No. 1

applying the highest rate of taxation, $20 \%$ in the UK, $22 \%$ in Slovenia and $21 \%$ in the Netherlands.

For any additional taxes on Yachting firms, the UK and the Netherlands do not impose taxes other than those applicable to all other businesses, while among the other countries Croatia has the largest additional tax with $€ 771$, followed by Greece with $€ 583$ (also calculating TRDB) and Slovenia the least tax charge of $€ 138$.

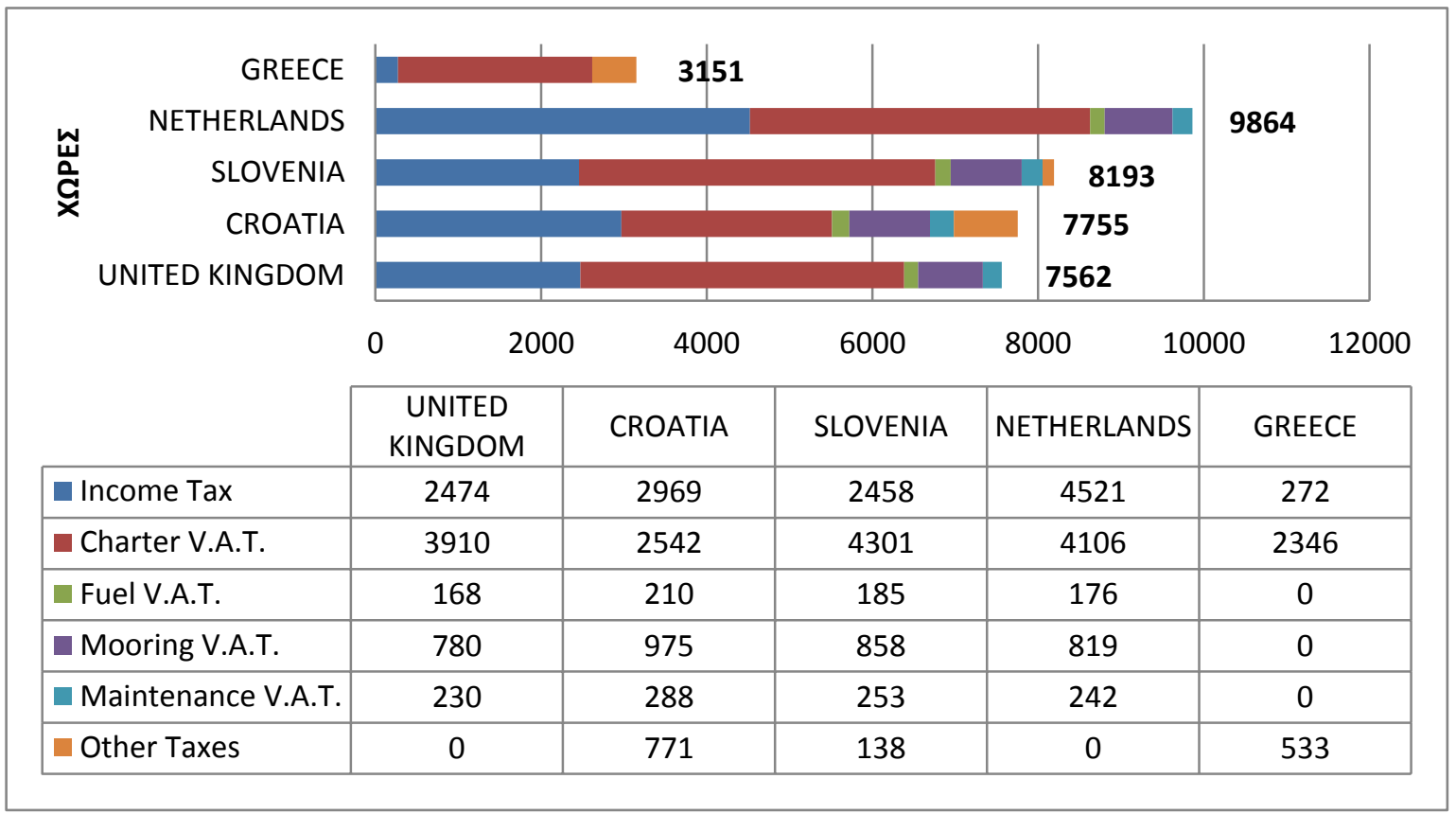

Figure 2. Annual total Tax burden on the professional yacht of a Physical Entity

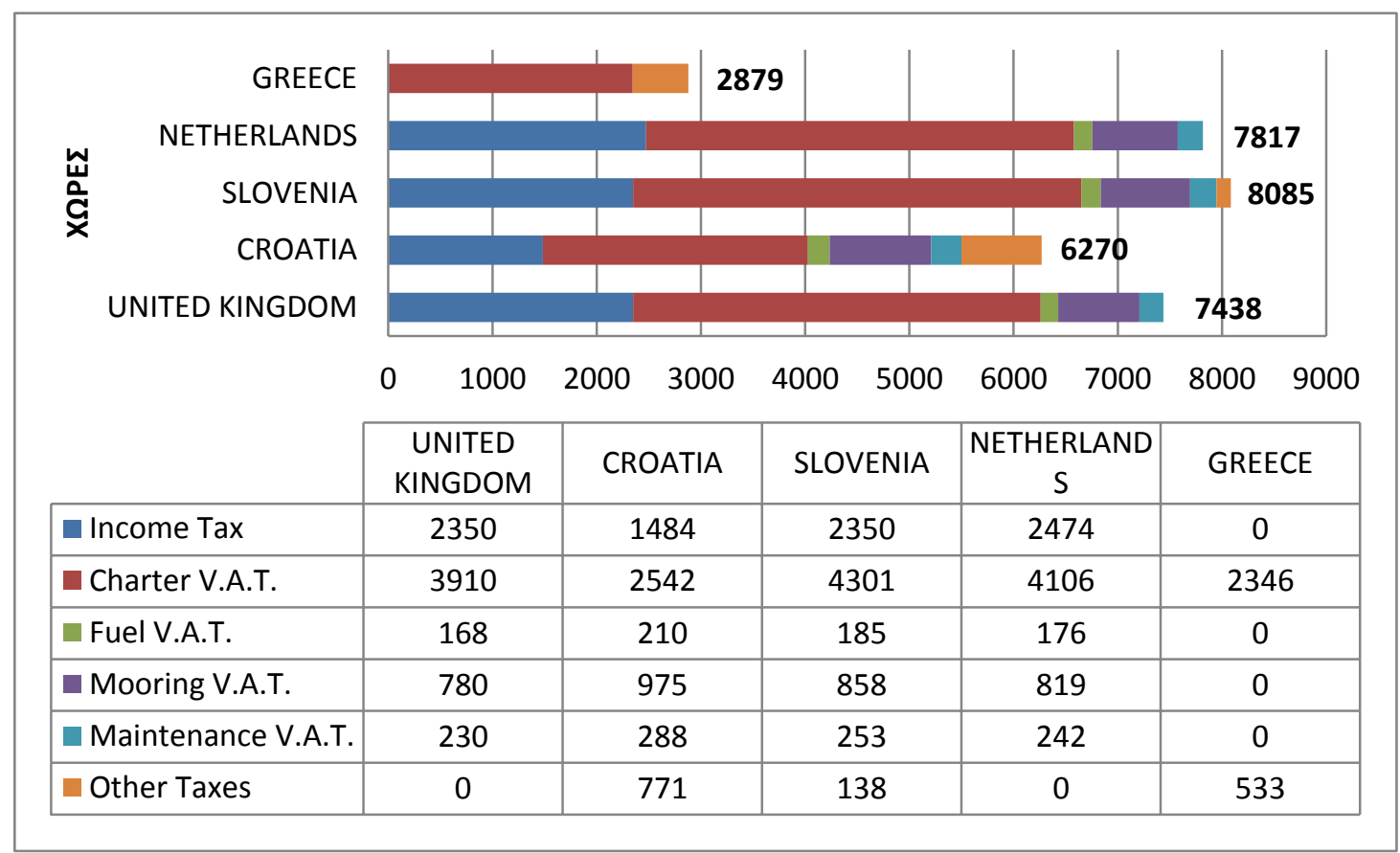

Figure 3. Annual total Tax burden on the professional yacht of a Legal Entity 


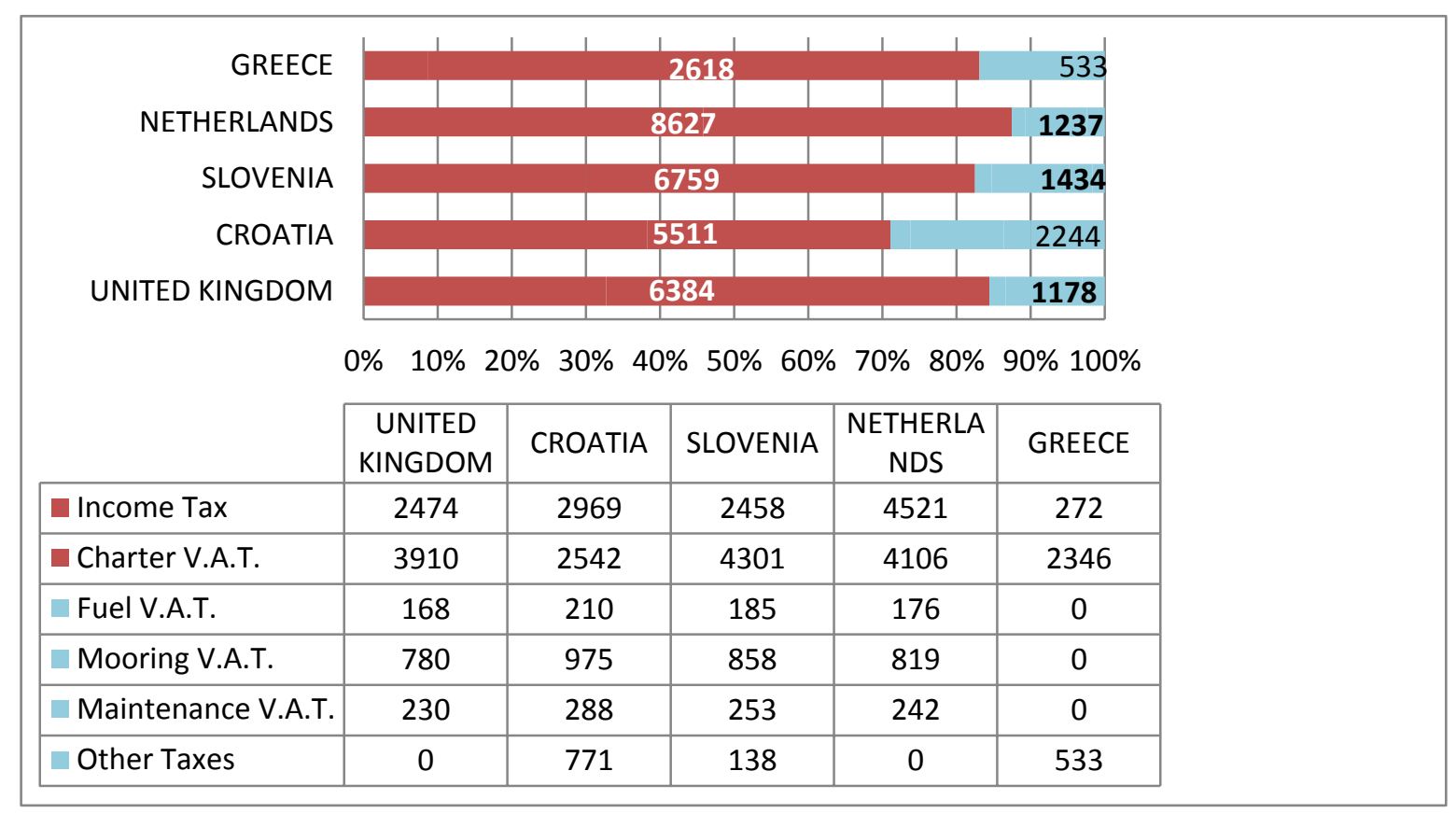

Figure 4. Income Tax and V.A.T. on the total Tax cost

\section{Comparative Tables}

The empirical research shows the tax regime governing the enterprises operating in professional yachting in Greece and in the European countries concerned. Displayed below are the comparative tables and graphs on the main taxes and tax rates on the most important costs as they emerged from our research. 


\section{Macrothink}

Business and Economic Research ISSN 2162-4860

Table 21. Income Tac burden on businesses operating recreational yachs, by country

\begin{tabular}{|c|c|c|c|c|c|c|c|c|c|c|c|c|c|c|c|c|c|c|c|c|c|c|c|c|}
\hline \multicolumn{25}{|c|}{ INCOME TAX BY COUNTRY } \\
\hline \multicolumn{21}{|c|}{ PHYSICAL ENTITIES } & \multicolumn{4}{|c|}{ LEGAL ENTITIES } \\
\hline In $0,000 €$ & $>8$ & $>12$ & 20 & 20,1 & 20,4 & 28,2 & $>28,2$ & 30 & 34 & 38,3 & 40 & 48 & $>48$ & 65 & 68,5 & $>68,5$ & 171,6 & $>171,6$ & 220 & $>220$ & $<200$ & $>200$ & $<400$ & $>400$ \\
\hline U.K. & & & & & & & & & & 20 & & & & & & & 40 & 45 & & & 19 & 19 & 19 & 19 \\
\hline CROATIA & & & & & & 24 & 36 & & & & & & & & & & & & & & 12 & 12 & 12 & 18 \\
\hline SLOVENIA & 16 & & & & 27 & & & & & & & 39 & 50 & & & & & & & & 19 & 19 & 19 & 19 \\
\hline NETHERLANDS & & & & 36,55 & & & & & 40,85 & & & & & & 40,85 & 51,95 & & & & & 20 & 25 & 25 & 25 \\
\hline GREECE* & & 2,2 & 2,2 & & & & & 5 & & & 6,5 & & & 7,5 & & & & & 9 & 10 & - & - & - & - \\
\hline
\end{tabular}

*Solidarity levy. Source: Authors' elaboration

Table 22. Comparing Fixed cost of Recreational Yacht according to Greek Maritime Chamber and Objective Tax Criteria

\begin{tabular}{|l|l|l|l|l|l|}
\hline Comparing Fixed cost of Recreational Yacht according Objective Tax Criteria \\
\hline Total lenght (LOA) & $4-10 \mathrm{~m}$ & $10-15 \mathrm{~m}$ & $15-20 \mathrm{~m}$ & $20-25 \mathrm{~m}$ & Over 25m \\
\hline Expenses (based on Empirical Research) & 2.500 & 6.100 & 19.800 & 47.700 & 107.000 \\
\hline Objective Tax Criteria & $9.400-14.700$ & $14.700-56.700$ & $56.700-145.950$ & $145.950-292.950$ & $292.950+50.000 / \mu \dot{\varepsilon} \tau \rho 0$ \\
\hline
\end{tabular}

Source: Authors' elaboration

Table 23. V.A.T. rates burdening the cost of professional yachts by country

\begin{tabular}{|l|l}
\hline V.A.T. RATES BURDENING THE MAIN COST OF PROFESSIONAL YACHTS BY COUNTRY \\
\hline COST
\end{tabular}

\begin{tabular}{|c|c|c|c|c|c|c|}
\hline \multirow[t]{2}{*}{ COST } & Charter & Mooring & Boat Acquisition & \multicolumn{3}{|c|}{ Materials, equipment and services incorporated in the Boat acquisition } \\
\hline & & & & MATERIALS AND EQUIPMENT & SERVICES & FUEL \\
\hline COUNTIER & $\%$ & $\%$ & $\%$ & $\%$ & $\%$ & $\%$ \\
\hline U.K. & 20 & 20 & 20 & 20 & 20 & 20 \\
\hline CROATIA & $13^{*}$ & 25 & 25 & 25 & 25 & 25 \\
\hline SLOVENIA & 22 & 22 & 22 & 22 & 22 & 22 \\
\hline NETHERLANDS & 21 & 21 & 21 & 21 & 21 & 21 \\
\hline NETHERLANDSCCV & EXCEMPTED*** & 21 & EXCEMPTED & EXCEMPTED & EXCEMPTED & EXCEMPTED \\
\hline GREECE & $12 * * * *$ & EXCEMPTED & EXCEMPTED & EXCEMPTED & EXCEMPTED & EXCEMPTED \\
\hline
\end{tabular}

* It applies on Chartering including overnight stay. ** Yachts $>24 \mathrm{~m}$. overall length.

*** If the place of destination or the place of embarkation is outside the Netherlands.

**** They are classified in Category II as Tourist boats operating Local to Open Seas trips. 


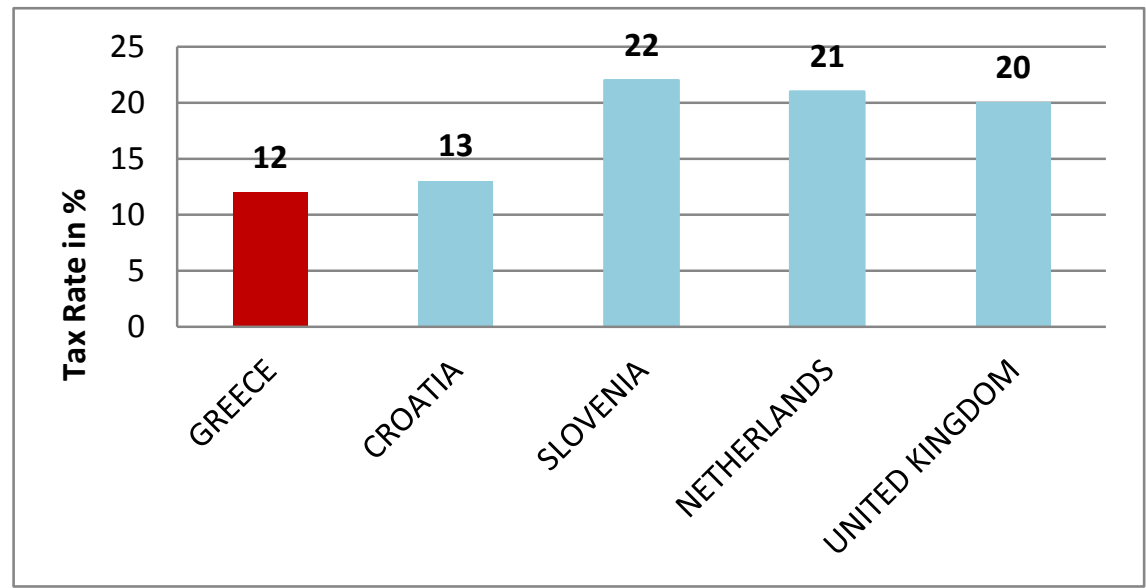

Figure 5. V.A.T. rate (\%) on Charter by country

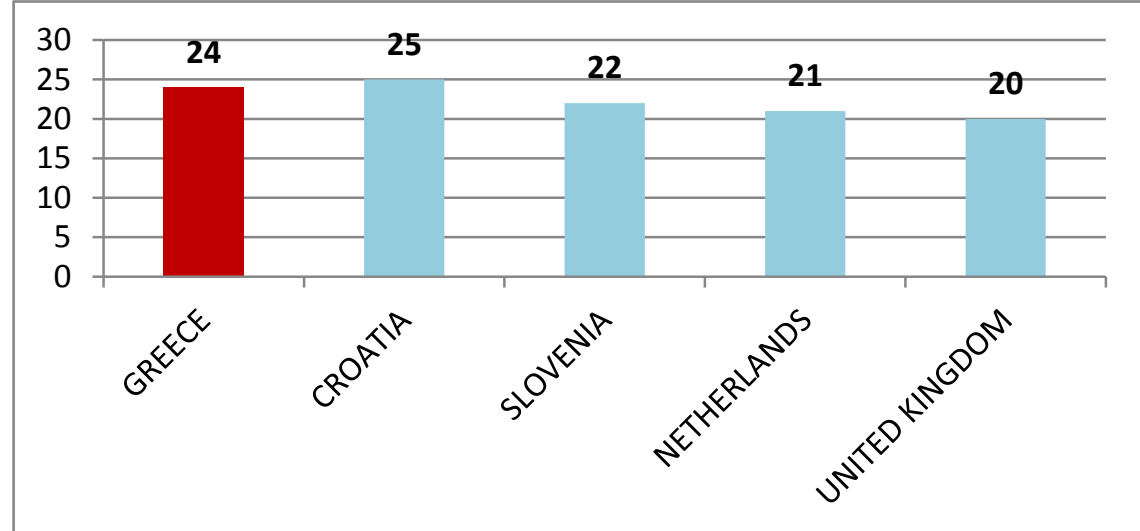

Figure 6. V.A.T. rate (\%) on Mooring by country* for Greece is applied only on Private boats. Professional boats are exempted

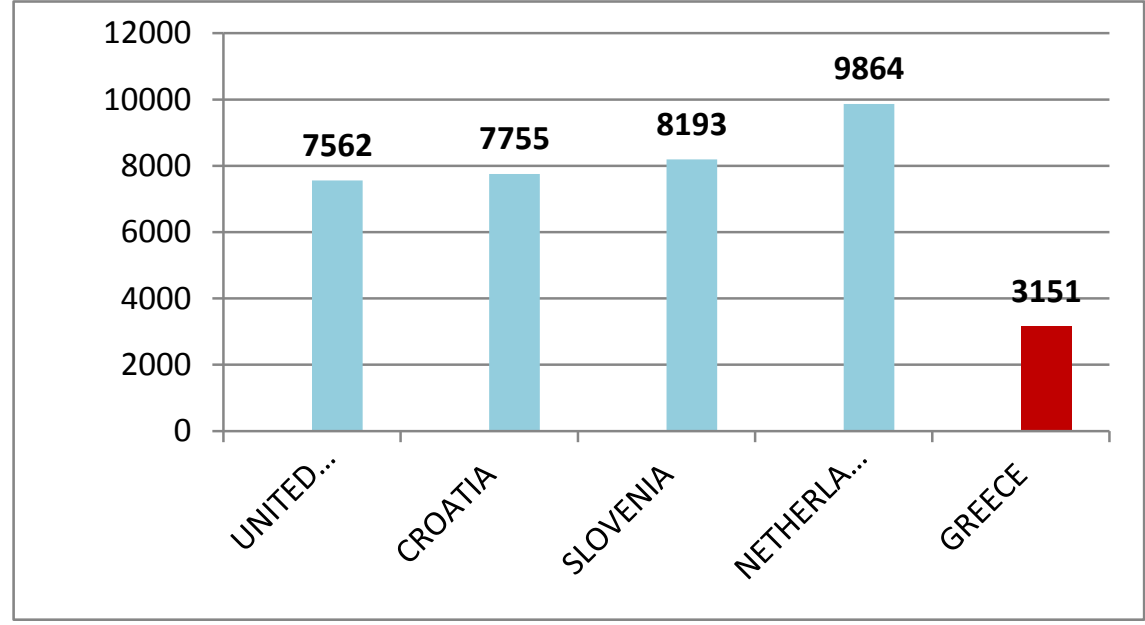

Figure7. Annual Tax burden of Professional yachts of Physical Entities 


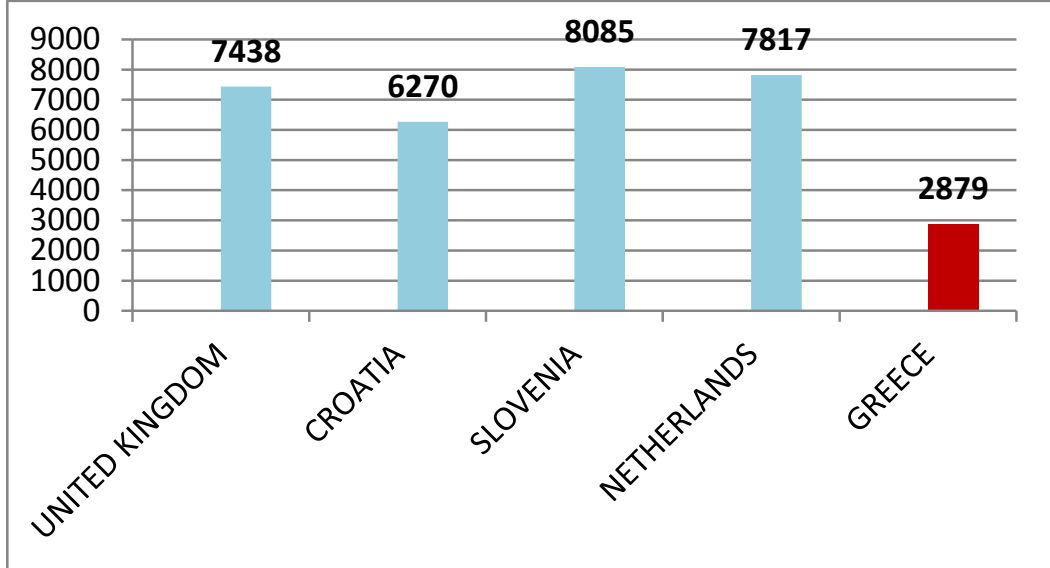

Figure 8. Annual Tax burden of Professional yachts of Legal Entities

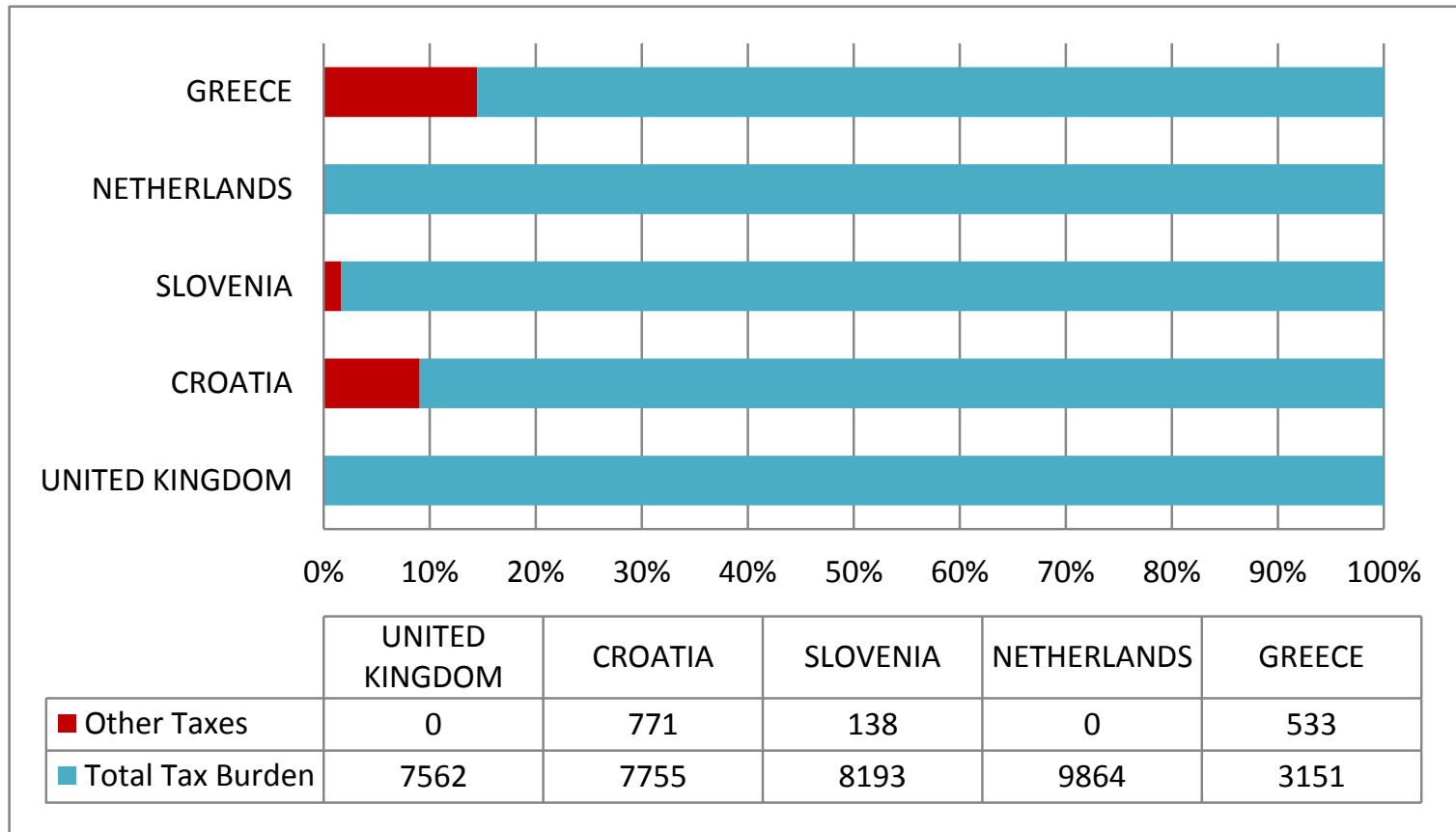

Figure 9. Percentage of other taxes in the total annual tax burden by country

\section{Conclusions}

According to the findings of this research as well as from the results of the comparative example, regarding the real tax burden of enterprises engaged in professional yachting, professional yachting in Greece has by far the lowest total annual tax burden in relation to other comparable countries, for all kinds of recreational boats.

The Income Tax on Small and Medium-sized Enterprises with a net profit of up to $€ 50,000$, has a virtually zero tax burden, with the only charge being a $6.5 \%$ Solidarity Contribution. Slovenia has the highest tax burden with $50 \%$ followed by the Netherlands with $40.85 \%$, Croatia with $36 \%$ and the UK with $20 \%$. The same applies to Income Tax for Legal Entities, where tax burden in Greece is zero as there is no Solidarity Fee. For the other countries and 
for firms with profits up to $€ 200,000$ the taxation is almost the same (UK and Slovenia $19 \%$ and the Netherlands 20\%) with the exception of Croatia applying a rate of $12 \%$ and certainly becoming the most attractive country in the category. It is worth noting that there are no special income tax exemptions on net profits in yachting in any of the considered countries, except Greece.

Examining the VAT rates applied to the main costs of professional yachting in each country, it is noted that with the exception of the chartering cost, there is a full exemption in Greece (we do not consider the CCV category in the Netherlands, which is a special case). Croatia applies a rate of $25 \%$ (excluding chartering), Slovenia $22 \%$, the Netherlands $21 \%$ and the UK $20 \%$. By focusing on the VAT rate charged on the charter, which is a very important criterion to attract customers, we see that while all other countries apply the standard rate, Greece and Croatia charge $12 \%$ and $13 \%$ respectively in most cases for the reasons discussed above. This certainly makes them more competitive to attract customers, and use this comparative advantage over other European Union members (e.g. Slovenia).

It should be noted that the case of the special Status of Small Enterprises which are VAT exempted has not been included in the comparison, since the amount of gross income required as a precondition for joining this category is low and does not essentially concern the yachting firms.

The other taxes burdening professional yachting do not exist in the case of the Netherlands and the UK, while in Greece they account for $16.9 \%$ of the total tax costs (including TRDB), Croatia $9.9 \%$ and Slovenia $1.7 \%$.

All of the above are confirmed by the results of the comparative example mentioned, in which Greece has the lowest burden compared to other countries. Thus, Croatia, which is Greece's main competitor, charges 2,5 and 2 times more taxes on natural and legal entities respectively, operating in the field of yachting. This difference is increasing compared with other countries, among which Netherlands has the highest burden on physical entities with $€$ 8,193 and Slovenia with $€ 8,085$ in legal entities.

Summarizing we conclude that the level of the tax burden on professional yachting in Greece influences, though not decisively, the formation of the current situation, and its contraction in recent years. The main reasons that have led professional yachting to the above situation and which arise from this research are:

- The complexity and mainly the constant volatility that distinguishes the institutional and especially the fiscal framework governing the sector in Greece. Taking a historical retrospection from 1975 until today, the situation described above can easily be distinguished, and in particular the continuous changes in the tax framework from the beginning of the economic crisis with the Law 3790/2009 and thereafter.

Additional reasons which are confirmed by other surveys:

- Lack of sufficient number of berths, and of high level services provided. Lack of certified vocational training mainly of staff working in small public tourist ports. 
- Pirated charters from professional boats with a foreign flag that create unfair competition. Under Law 4504/17, there is a total prohibition of chartering in Greece and performing a charter contract by a professional leisure boat flying the flag of a Member State of the European Union or of the European Economic Area or flag outside the EU, except where the place of boarding and disembarking of the passengers of the leisure boat is abroad.

\section{References}

Chatzimanolaki, E. (2011). Maritime Tourism and the situation of Greece. Comparisons and Opportunities. MSc Desertation, University of Piraeus. [Online] Available:

http://dione.lib.unipi.gr/xmlui/bitstream/handle/unipi/4302/Xatzimanolaki.pdf?sequence=2\&i sAllowed=y

Croatian Parliament, (2008). Decision promulgating the sojourn tax act. [Online] Available: http://www.cruiselaws.com/CruiseLaws/Cruise_Laws_Croatia_Sojourn_Tax_Act.pdf

Diakomihalis, M. (2012). Maritime Tourism Tax Revenues in Greece: A New Framework for Collection. International Journal of Economic Sciences and Applied Research, 5(1), 109-127. [Online] Available: http://www.ijesar.org/docs/volume5_issue1/maritime_tourism.pdf

Diakomihalis, M., \& Lagos, D. (2011). An empirical approach to coastal leisure shipping in Greece and assessment of its economic contribution. Tourism Economics, 17(2), 437-456. https://doi.org/10.5367/te.2011.0038

Diakomihalis, M. (2011). The Role of Port and Refuelling Costs in Yachting Development in Greece. 4th International Confirence, Entrerreneurship in the Global Environment: New Challenges in the Post-Crisis Era (pp. 249-264). Preveza: TEI of Epirus.

Diakomihalis, M., \& Atlay, I. D. (2011). Maritime Tourism Potential in the Aegean: A comparative study of Yachting Development in Greece islands and Turkish coastline. Advances in Hospitality and Tourism Marketing and Management. Istanbul: Technological Educational Institute of Epirus, Mugla University Dalaman Vocational School.

Diakomihalis, M. (2009). Maritime Tourism and its Economic impacts. Stamoulis Editions, Athens

Diakomihalis, M., \& Lagos, D. (2008). Estimation of the economic impacts of yachting in Greece via the tourism satellite account. Tourism Economics, 14(4), 871-887.

https://doi.org/10.5367/000000008786440139

Diakomihalis, M. (2007a). The Impact of Maritime Tourism on the Greek Economy via the Tourism Satellite Account. Tourism and Hospitality Planning \& Development, 4(3), 231-243. https://doi.org/10.1080/14790530701783640

Diakomihalis, M. (2007b). Greek Maritime Tourism: Evolution, Structures and Prospects. Research in Tranportation Economics, 21, 423-460.

https://doi.org/10.1016/S0739-8859(07)21013-3

Fourla, D. M. (2016). At "immobility" over 9,300 boats due to a Luxury Living Tax! [Online] 
Available: http://www.dimokratiki.gr/24-02-2016/se-akinisia-pano-apo-9-300-skafi-logo-foro u-politelous-diaviosis/

Fourla, D. M. (2017). Yachtinf tourism on recovery. [Online] Available:

http://www.dimokratiki.gr/28-02-2017/anakampti-o-tourismos-tou-yachting/

Hellenic Chamber of Shipping (H.C.S.). (2012). Study for appointing the meaning of leasure boats on Maritime Tourism and on the National Economy (in Grek). [Online] Available: http://nee.gr: http://nee.gr/downloads/184STUDY_ON_YACHTING.pdf

Kotsis, V. (2012). Yacht owners are "sailing" to Turkey and Croatioa. [Online] Available: http://www.tovima.gr/finance/article/?aid=456208

Manologlou, S. (2017). The Private yaching sector in Greece. Development trends and prospects. [Online] Available:

http://www.jmc.uoa.gr/fileadmin/jmc.pspa.uoa.gr/uploads/PDFs/20170424_Yachting_thalassi os_toyrismos_-_Manologloy.pdf

Mavrigiannakis, A. (2017). The new levy on Tax of Recreational and Day Boats (TRDB). [Online] Available:

https://www.boatfishing.gr/neo-telos-ploion-anapsychis-kai-imeroploion-tepah/

Minford, L. (2016). Tax Regulation and Growth: Understanding the Research. In: Taxation, Government Spending and Economic Growth (pp. 122-141). London: The Institute of Economic Affairs.

Republic of Croatia. (2018a). Income Tax Act. [Online] Available:

http://www.porezna-uprava.hr/en_propisi/_layouts/in2.vuk.sp.propisi.intranet/propisi.aspx\#id $=$ pro 135

Republic of Croatia. (2018b). Profit Tax Act. [Online] Available:

http://www.porezna-uprava.hr/en_propisi/_layouts/in2.vuk.sp.propisi.intranet/propisi.aspx\#id $=$ pro133

Republic of Croatia. (2018c). Value Added Tax Act. [Online] Available:

http://www.porezna-uprava.hr/en_propisi/_layouts/in2.vuk.sp.propisi.intranet/propisi.aspx\#id $=$ pro134

Republic of Slovenia - Ministry of Finance. (2018). Taxation in Slovenia 2018. [Online] Available:

http://www.mf.gov.si/fileadmin/mf.gov.si/pageuploads/Davki_in_carine/Angleški/Taxation_i n_Slovenia_2018.pdf

Republic of Slovenia - Ministry of Finance. (2016). Value added tax (VAT). [Online] Available:

http://www.fu.gov.si/en/taxes_and_other_duties/areas_of_work/value_added_tax_vat/

Republika Slovenija - Ministrstvo za Finance. (2017). Obvestilo o lestvici za odmero dohodnine in olajšave za leto 2018. [Online] Available: 


\section{Macrothink}

Business and Economic Research

ISSN 2162-4860 2020, Vol. 10, No. 1

http://www.fu.gov.si/fileadmin/Internet/Davki_in_druge_dajatve/Podrocja/Dohodnina/Letna_ odmera_dohodnine/Opis/Lestvica_za_leto_2018.pdf

SETE. (2015). Existing Situation and Prospects of Maritime Tourism - Policy proposals SETE.gr, Greece

Siahos, M. (2017). What will be the evolution of the overnights levy and trip for pleasure boats and small boats. [Online] Available:

https://www.dikaiologitika.gr/eidhseis/oikonomia/142700/ti-tha-ginei-me-to-telos-paramoniskai-ploon-gia-ploia-anapsyxis-kai-mikra-skafi

\section{Copyright Disclaimer}

Copyright for this article is retained by the author(s), with first publication rights granted to the journal.

This is an open-access article distributed under the terms and conditions of the Creative Commons Attribution license (http://creativecommons.org/licenses/by/3.0/). 